\title{
Scots pine needles macronutrient (N, P, K, CA, MG, and S) supply at different reclaimed mine soil substrates -as an indicator of the stability of developed forest ecosystems
}

\author{
Marcin Pietrzykowski • Bartlomiej Woś • Nicholas Haus
}

Received: 27 September 2012 / Accepted: 21 January 2013 /Published online: 13 February 2013

(C) The Author(s) 2013. This article is published with open access at Springerlink.com

\begin{abstract}
A main objective of restoration and afforestation at post-mining sites is establishing a long-term sustainable ecosystem which depends on adaptations of tree species and which in turn depends on the soil nutrient flux. The nutrient concentration (nitrogen $(\mathrm{N})$, $\mathrm{P}, \mathrm{K}, \mathrm{Ca}, \mathrm{Mg}$, and sulfur (S)) of Scots pine needles was investigated in reclaimed mine soils (RMS) located at the following post-mining sites: a sand mine pit, spoil heap from a lignite mine, spoil heap from a $\mathrm{S}$ mine, and a carbonaceous spoil heap from an underground coal mine. The control plots were arranged on natural forest sites adjacent to the post-mining sites. A higher level of foliar nutrients was noted in the carbonaceous RMS, while lower levels were found in RMS on the spoil heap following lignite mining. The characteristics of the substrate were found to exert greater effect than mineral fertilization (performed at the onset of reclamation) on the tree stand characteristics, needle length and foliar nutrient concentration. While the soils and trees were most deficient in $\mathrm{N}$, negative symptoms have not been noted to this date in tree stands at reclaimed mine sites. Trophic ratings were recommended based on statistical
\end{abstract}

M. Pietrzykowski $(\bowtie) \cdot$ B. Woś

Department of Forest Ecology, Forest Faculty, University of Agriculture in Krakow, Al. 29 Listopada 46,

Pl. 31-425 Krakow, Poland

e-mail: rlpietrz@cyf-kr.edu.pl

N. Haus

Department of Soil Science, University of Wisconsin,

Madison, WI 53715, USA correlations and groupings between $\mathrm{N}$ and $\mathrm{P}$ contents in needles and needles length (mean length of 300 needles) while nutrient ratings were recommended from statistical differences and groupings of the RMS substrates.

Keywords Mining sites · Reclamation · Afforestation · Ecosystem $\cdot$ Pine $\cdot$ Nutrient supply
Abbreviations
BEL
Bełchatów (mine sites
(facilities))
PIAS Piaseczno (mine sites
(facilities))
SCZ Szczakowa (mine sites
(facilities))
SMOL Smolnica spoil heaps and quarry (mine sites (facilities))
BEL-Q1, BEL-Ns, PIAS- Soil-substrate (parent rock) Qs, PIAS-QsNc, SCZ-Qs,variants on post-mine sites, SCZ-Qls, SMOL-Cf detailed description in Table 1 d.b.h. The trees diameter at a breast height of $1.3 \mathrm{~m}$

$\mathrm{Dg}$
$\mathrm{DM}_{100 n}$
$G$
$\mathrm{H} 100$
$\mathrm{HL}$
$L_{300 n}$ Average mean of d.b.h. Dry mass of 100 pairs of needles Area of stand cross-section at breast height of trees Top height of tree stand Average height of tree stand Mean length of 300 pine needles 
$N$

$\begin{array}{ll}\text { NFS } & \text { Natural forest sites } \\ \text { RMS } & \text { Reclaimed mine soils } \\ \text { SDI } & \text { Reineke's Stand Density } \\ & \text { Index } \\ \text { SI } & \text { Site index } \\ \text { TEB } & \text { Total exchangeable bases }\end{array}$

\section{Introduction}

Mined lands are drastically disturbed landscapes in need of soil reclamation to re-establish vegetation. Successful reclamation of mined lands requires site-specific strategies (Wali and Freeman 1973; Daniels et al. 1992; Wali 1999; West and Wali 2002; Bradshaw and Chadwick 1980; Bradshaw and Hüttl 2001; Hüttl and Weber 2001; Pietrzykowski and Krzaklewski 2007). Afforestation is a potentially sustainable strategy for reclaiming mine lands to their former state (Parrotta et al. 1997; Filcheva et al. 2000; Singh et al. 2002; Dutta and Agrawal 2003; Pietrzykowski and Krzaklewski 2007). In central Europe, a large proportion of post-mining landscapes are reclaimed to forest (Katzur and Haubold-Rosar 1996; Hüttl 1998; Hüttl and Weber 2001; Kaar 2002; Knoche et al. 2002; Pietrzykowski and Krzaklewski 2007). In Poland, lands disturbed by mining and the power industry are estimated at around 70,000 ha, approximately 25,000 of which has been reclaimed and returned to forest (Krzaklewski 2001; Pietrzykowski and Krzaklewski 2007).

From an ecological point of view, the goal of restoration is to develop a long-term sustainable ecosystem native to the area mined (Chambers et al. 1994; Bradshaw and Hüttl 2001). The ecosystem, according to the traditional definition (Golley 1993), should consist of an integrated system of biotic and abiotic elements where all the trophic layers contain a complete set of species ensuring the circulation of matter and energy flow. A complete assessment of the reclamation and afforestation processes should take into consideration many ecological factors (Rodrigue et al. 2002). Of particular importance is the need to understand soils processes, element flux (Bradshaw 1983; Daniels et al. 1992; Li and Daniels 1994; Bendtfeldt et al. 2001; Schaaf 2001; Knoche et al. 2002; Pietrzykowski 2010a) and energy balance (Pietrzykowski and Krzaklewski 2007).
In recent years, interest in tree species selection and their adaptation to post-mining sites has grown (Baumann et al. 2006; Chodak and Niklińska 2010; Kuznetsova et al. 2010; Pietrzykowski 2010a; Pietrzykowski and Socha 2011). Scots pine (Pinus sylvestris $\mathrm{L}$.) is one of the most important species used for reclaiming mined lands in central Europe (Baumann et al. 2006; Pietrzykowski 2010a; Kuznetsova et al. 2010). Scots pine is native to Europe and Asia and has a common range extending west to Great Britain and to Portugal, east to eastern Siberia, south to the Caucasus Mountains, and as far north as the Arctic Circle in Scandinavia. In its northernmost range, the Scots pine is found at altitudes ranging from sea level to $1,000 \mathrm{~m}$, while in the south, it is a highaltitude tree found between 1,200 and $2,600 \mathrm{~m}$ (Farjon 2005). The pioneering character of Scots pines over such a vast area coupled with its tolerance of poor soils makes it an ideal species for reclamation and reforestation in central Europe. However, post-mining sites differ significantly from natural sites; water and nutrient limitations are the foremost impediments to tree stand growth and stability on disturbed lands (Howard et al. 1988; Katzur and Haubold-Rosar 1996; Knoche et al. 2002; Ochał et al. 2010; Pietrzykowski 2010a; Zipper et al. 2011). The adaptability of Scots pine to these environments must be studied further (Baumann et al. 2006; Pietrzykowski and Krzaklewski 2007; Ochał et al. 2010; Pietrzykowski 2010a).

The nutritional status of pines in different habitats is primarily assessed by the content and relative abundance of macronutrients in the needles (Ballard and Carter 1986; Braeke and Sahin 2002). This criterion can also be used to assess reclaimed mine soil (RMS) nutrient status (Pietrzykowski 2010a) based on the correlation between nutrient availability in the soil versus nutrient content in the foliage (Braeke and Sahin 2002), though these correlations between nutrient and foliar RMS are in need of further proofing (Heinsdorf 1999; Baumann et al. 2006; Ochał et al. 2010; Pietrzykowski 2010a; Pietrzykowski and Socha 2011). More traditional criteria assess the morphology of the needles (i.e., needle weight and length) and growth of tree stands (mean height and mean diameter at a breast height of $1.3 \mathrm{~m}$ ) (Baule and Fricker 1970; Ballard and Carter 1986).

This study evaluated the afforestation of Scots pine on four reclaimed mine spoils. The main goal of the 
study was to analyze and compare nutrient supply from different RMS substrates to the foliar and tree stand characteristics on post-mining lands afforested with Scots pine. The results were compared with data from "natural" control plots adjacent to the RMS.

\section{Materials and methods}

Site factors

Research plots were located in Poland, on 12- to 30year-old stands of Scots pine, at four reclaimed and afforested mining facilities on seven different RMS substrates. The post-mining sites and the RMS substrates used were: (1) two locations on the summit of a spoil heap following open cast lignite mining at the KWB "Bełchatów" (BEL) mine, (2) a carbonaceous spoil heap at the "Smolnica" hard rock coal mine (SMOL), (3) two locations in an excavated sand mining pit at the "Szczakowa" mine (SCZ), and (4) two locations on the summit of an external spoil heap of rock overburden at the "Piaseczno" sulfur mine (PIAS). Control plots were located near the mining facilities in natural forest sites (NFS), on tree stands of the same age class (30 years old). All the NFS soils were classified as Haplic Podzols according to the World Reference Base for Soil Resources (WRB) (IUSS Working Group WRB 2006), which are known to sustainably support Scots pine (Farjon 2005). Details of the sites characteristics and reclamation treatments are described in Table 1.

\section{Site measurements}

A total of thirty-two $10 \times 10 \mathrm{~m}$ plots were established; 28 were on RMS (4 replications $\times 7$ RMS substrates) and 4 were control plots on NFS. The tree diameters at a breast height of $1.3 \mathrm{~m}$ (d.b.h.) and tree heights $(h)$ were measured on each plot. These dendrometric measurements were used to calculate the following tree stand characteristics: average mean d.b.h. (Dg); average height (HL); number of trees per ha $(\mathrm{N})$; area of stand crosssection at breast height $(\mathrm{G})$; average height of the 100 highest trees per hectare (H100). Reineke's Stand Density Index (SDI) was computed to describe tree stand density (Shaw 2000). Reineke's SDI is a relative measure of stand density that is determined from the number of trees per hectare
(N) and average d.b.h. (as d.b.h. ${ }_{\mathrm{q}}$, the quadratic mean diameter in $\mathrm{cm}$ ):

$S D I=N\left(\frac{d \cdot b \cdot h \cdot q}{25}\right)^{1.605}$

Branches were sampled and collected during the autumn of 2007 and 2008 from treetops on a southwest exposure from three trees with mean parameters (d.b.h. and $h$ ) at each plot.

The youngest needles (from the sampling year) were separated from the collected branches in the laboratory and representative mixed samples for each research plot were prepared. Three hundred (300) pairs of needles $\left(L_{300 n}\right)$ from the representative mixed samples were selected randomly and their length (at $0.0 \mathrm{~cm}$ accuracy) was measured. The $L_{300 n}$ samples were then dried at $65^{\circ} \mathrm{C}$, weighed (at $0.0 \mathrm{~g}$ accuracy) to determine the dry mass of 100 pair of needles $\left(\mathrm{DM}_{100 n}\right)$, washed in distilled water, dried again, and prepared for chemical analyses.

The carbon (C), N, and $\mathrm{S}$ content of the needles was assayed on a "Leco CNS 2000" analyzer. Organic carbon $\left(\mathrm{C}_{\mathrm{org}}\right)$ and total sulfur $\left(\mathrm{S}_{\mathrm{t}}\right)$ content was measured by infra-red absorption, and total nitrogen $\left(\mathrm{N}_{\mathrm{t}}\right)$ by thermal conductivity; Total $\mathrm{Ca}$, $\mathrm{Mg}, \mathrm{K}$ was determined by digestion in the mixture of $\mathrm{HNO}_{3}(d=1.40)$ and $60 \% \mathrm{HClO}_{4}$ acid in a $4: 1$ ratio; element levels were determined by atomic absorption spectroscopy. Total phosphorus (P) was determined by photocolorimetry by the molybdate blue method of Ostrowska et al. (1991) from a $60 \% \mathrm{HClO}_{4}$ extract.

Soil characteristics

Soil pedons were sampled and analyzed (reported in Pietrzykowski 2010b), from 32 hand-dug pits to a depth of $110 \mathrm{~cm}$ for RMS and $150 \mathrm{~cm}$ for NFS controls. Full profile descriptions with detailed soil morphology were completed for each of the seven RMS substrates and the 4 adjacent NFS locations. The typical pedons were located on sites representative of the local relief and average tree growth of the stands. Additionally, five samples were collected from each plot by soil auger (Eijkelkamp set) on a grid. Boreholes were sampled at depths of 0-8, $8-50$, and $50-110 \mathrm{~cm}$. Bulk density was sampled from each soil horizon with 3 replications using 


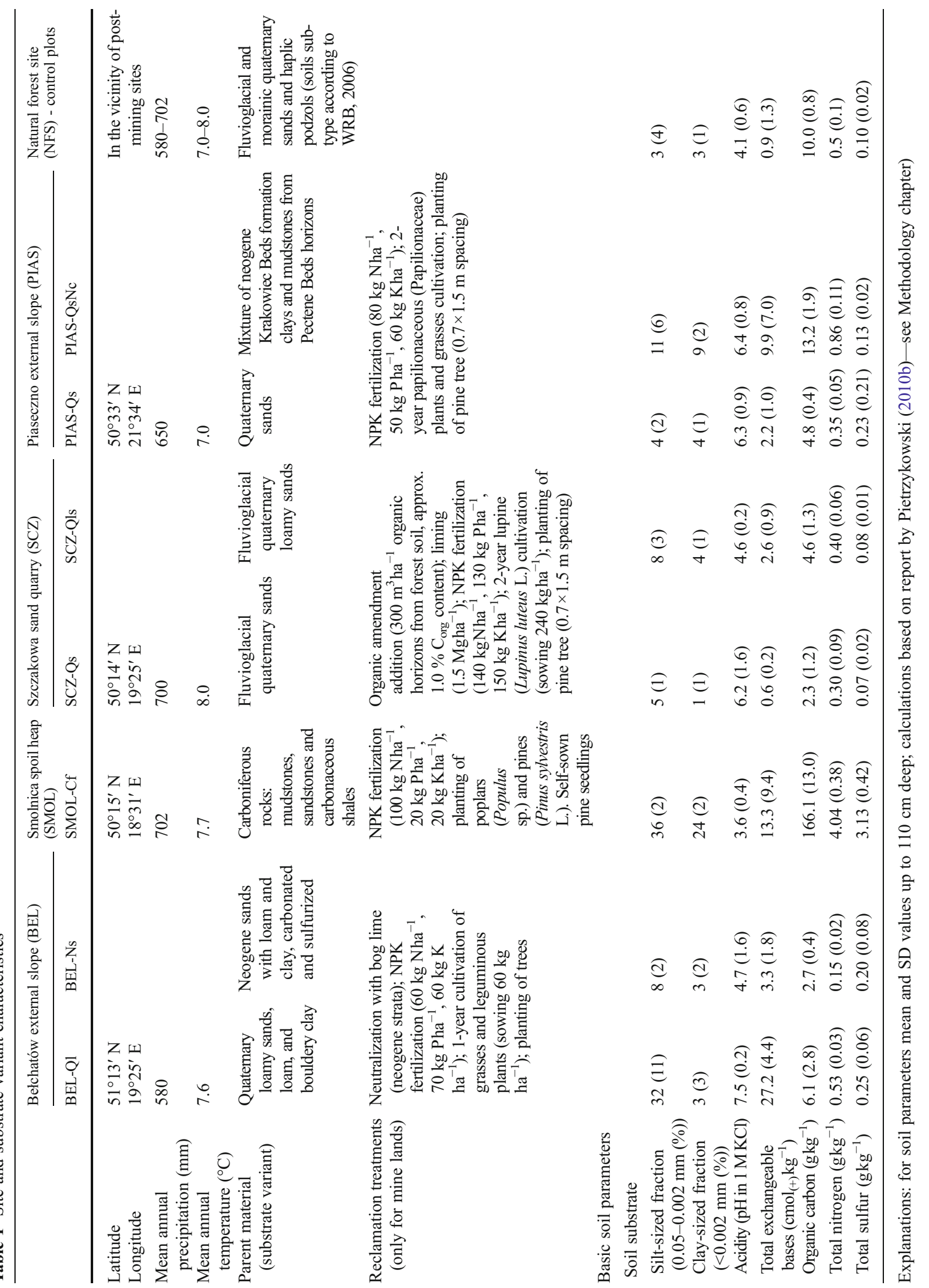


$250 \mathrm{~cm}^{3}$ steel cores according to the method of De Vos et al. (2005). Soil analyses were conducted on $<2 \mathrm{~mm}$ air-dried samples using the procedures of Ostrowska et al. (1991) and Van Reeuwijk (1995). Particle size distribution was determined by hydrometer and sand fractions by sieving. Soil $\mathrm{pH}$ was determined in a $1: 2.51 \mathrm{M} \mathrm{KCl}$ solution, exchangeable cations $\left(\mathrm{Ca}^{2+}, \mathrm{Mg}^{2+}, \mathrm{K}^{+}\right.$, and $\left.\mathrm{Na}^{+}\right)$ were extracted with $1 \mathrm{M} \mathrm{NH}_{4} \mathrm{OAc}$ and total exchangeable bases (TEB) were calculated. $\mathrm{C}_{\text {org }}$ and $\mathrm{S}_{\mathrm{t}}$ content was determined by infrared absorption, and $\mathrm{N}_{\mathrm{t}}$ by thermal conductivity with a "Leco CNS 2000." $\mathrm{P}$ in a form assimilated by plants was assayed using the Egner-Riehm method in calcium-lactate extract $\left(\left(\mathrm{CH}_{3} \mathrm{CHOHCOO}\right)_{2} \mathrm{Ca}\right)$ acidified with hydrochloric acid to $\mathrm{pH}$ 3.6. Nutrient storage $\left(\mathrm{Mgha}^{-1} 110 \mathrm{~cm}^{-1}\right.$ depth) was determined from the bulk density and nutrient concentrations (N, P, K, Ca, Mg, and S) (Pietrzykowski 2010b).

\section{Data analysis}

Data sets were statistically analyzed using the Statistica 8.1 program (StatSoft Inc. 2007). Pearson's procedure was used to test the first correlations at $P=0.05$ between: nutrient concentration and nutrient ratio in the needles; nutrient concentration, dry mass, and length of the needles; nutrient concentration and tree stands parameters (Dg and HL); and the biometric needle characteristics $\left(L_{300 n}\right.$ and $\left.\mathrm{DM}_{100 n}\right)$. Tukey's multiple comparison procedure was used to test the differences between mean values at $P=0.05$. Regression residuals were tested for normality using the Shapiro-Wilkes test. Means were grouped according to statistically similar $\mathrm{N}$ and $\mathrm{P}$ ranges.

\section{Results}

Soil characteristics

The RMS and NFS soils are generally coarse grained to skeletal with low nutrient contents. Large variations in physical and chemical properties are normal and can change drastically within the confines of a single mining facility. Soil $\mathrm{pH}$ ranged from extremely acid (3.6) to slightly alkaline (7.5) with large differences observed for similar RMS substrates given the same reclamation treatment (Table 1). Likewise, the exchangeable bases: $\mathrm{C}_{\text {org }}, \mathrm{N}_{\mathrm{t}}$, and $\mathrm{S}_{\mathrm{t}}$, also varied drastically under similar RMS substrates given the same reclamation treatment. With the exception of SMOL, the RMS properties ranged from 2.3 to $13.2 \mathrm{~g} \mathrm{~kg}^{-1}$ for $\mathrm{C}_{\text {org }}$, from 0.15 to $0.86 \mathrm{~g} \mathrm{~kg}^{-1}$ for $\mathrm{N}_{\mathrm{t}}$, and from 0.07 to $0.25 \mathrm{gkg}^{-1}$ for $\mathrm{S}_{\mathrm{t}}$. The SMOL substrate is extremely acid with a high content of geogenic $\mathrm{C}$ which contains much higher levels of carbon, $\mathrm{N}$ and $\mathrm{S}$ than other RMS substrates. The NFS soils were sandy ( $>90 \%$ sand), extremely acidic ( $\mathrm{pH} 4.1)$ and contained low organic (10 and $0.5 \mathrm{~g} \mathrm{~kg}^{-1}$ of $\mathrm{C}_{\text {org }}$ and $\mathrm{N}_{\mathrm{t}}$ ) and inorganic (TEB of $0.91 \mathrm{cmol}_{(+)} \mathrm{kg}^{-1}$ ) nutrients not dissimilar from many of the RMS substrates. In conclusion, the soils varied greatly due to properties inherited from the parent material substrate. The SMOL soils were the most nutrient rich but also the most acidic. The remaining, nutrient poor soils were markedly similar to the adjacent NFS soils (Table 1).

NFS mean nutrient storage at a depth of $110 \mathrm{~cm}$ was: $4.41 \mathrm{Mg} \mathrm{Nha}^{-1}, 0.03 \mathrm{Mg} \mathrm{Pha}^{-1}, 2.69 \mathrm{Mg} \mathrm{Ca}^{2+}$ $\mathrm{ha}^{-1}, 0.69 \mathrm{Mg} \mathrm{Mg}^{2+} \mathrm{ha}^{-1}, 0.24 \mathrm{Mg} \mathrm{K}^{+} \mathrm{ha}^{-1}$, and $1.8 \mathrm{Mg} \mathrm{Sha}^{-1}$. Comparatively, NFS nutrient storage was similar to the lower range of nutrients stored at
Table 2 Characteristics of tree stand parameters

Explanations: mean values for tree stands (four research plot replications for site variants)

$D g$ average mean d.b.h., $H L$ average height, $N$ number of trees per hectare, $G$ area of stand cross-section at breast height, $H 100$ height top, SDI the Reineke's Stand Density Index-see explanations in Methodology

\begin{tabular}{|c|c|c|c|c|c|c|c|}
\hline $\begin{array}{l}\text { Soil- } \\
\text { substrate } \\
\text { variants }\end{array}$ & $\begin{array}{l}\text { Age } \\
\text { (years) }\end{array}$ & $\begin{array}{l}\mathrm{N} \\
\left(\mathrm{pcsha}^{-1}\right)\end{array}$ & $\begin{array}{l}\mathrm{Dg} \\
(\mathrm{cm})\end{array}$ & $\begin{array}{l}\mathrm{G} \\
\left(\mathrm{m}^{2} \mathrm{ha}^{-1}\right)\end{array}$ & $\begin{array}{l}\mathrm{HL} \\
(\mathrm{m})\end{array}$ & $\begin{array}{l}\mathrm{H} 100 \\
(\mathrm{~m})\end{array}$ & SDI \\
\hline BEL-Q1 & 17 & 7,500 & 5.6 & 18.24 & 5.7 & 6.9 & 684.6 \\
\hline BEL-Ns & 12 & 6,375 & 2.9 & 4.11 & 3.3 & 4.4 & 203.1 \\
\hline SMOL-Cf & 30 & 1,500 & 15.2 & 27.14 & 15.2 & 17.2 & 674.3 \\
\hline SCZ-QLs & 21 & 2,550 & 11.3 & 25.36 & 10.5 & 12.1 & 710.8 \\
\hline SCZ-Qs & 23 & 4,000 & 9.3 & 27.31 & 9.3 & 11.0 & 825.0 \\
\hline PIAS-QsNc & 30 & 1,050 & 19.1 & 30.03 & 16.2 & 17.9 & 679.6 \\
\hline PIAS-Qs & 30 & 1,875 & 15.8 & 36.64 & 15.4 & 17.2 & 894.3 \\
\hline NFS & 30 & 2,150 & 16.7 & 35.74 & 16.5 & 18.5 & $1,127.4$ \\
\hline
\end{tabular}


RMS sites. The lowest RMS storage of macronutrients was: $3.10 \mathrm{Mg} \mathrm{Nha}^{-1}$ (BEL-Ns), $0.02 \mathrm{Mg} \mathrm{Pha}^{-1}$ (SCZQs), $2.33 \mathrm{Mg} \mathrm{Ca}^{2+} \mathrm{ha}^{-1}$ (SCZ-Qs), 0.12 $\mathrm{Mg} \mathrm{Mg}^{2+} \mathrm{ha}^{-1}$ (PIAS-Qs), $0.11 \mathrm{Mg} \mathrm{K}^{+} \mathrm{ha}^{-1}$ (SCZ-Qs), and $1.17 \mathrm{Mg}$ $\mathrm{S}_{\mathrm{t}} \mathrm{ha}^{-1}$ (SCZ-Qs). The highest macronutrient storage was: $62.3 \mathrm{Mg} \mathrm{Nha}^{-1}$ (SMOL-Cf), $0.48 \mathrm{Mg} \mathrm{Pha}^{-1}$ (BEL-Ns), $26.24 \mathrm{Mg} \mathrm{Ca}^{2+} \mathrm{ha}^{-1}$ (PIAS-QsNc), $3.10 \mathrm{Mg} \mathrm{Mg}^{2+} \mathrm{ha}^{-1}$ (SMOL-Cf), $0.97 \mathrm{Mg} \mathrm{K}^{+} \mathrm{ha}^{-1}$ (SMOL-Cf), and 69.6 Mg S $\mathrm{ha}^{-1}$ (SMOL-Cf). Although the storage of some nutrients is considerably higher especially at the Smolnica spoil heap, the majority of these nutrients are bound in geogenic materials such as shale and thus not available for plant uptake.

Tree stand characteristics

Tree stands investigated in this study ranged in age from 12 to 30 years (Table 2). The variation in the age of the tree stands strongly influenced the dendrometric characteristics on the RMS in comparison with the characteristics of the NFS control. The RMS measurement ranges and NFS means were: $\mathrm{N}$ from 1,050 (PIAS-QsNc) to $7,500 \mathrm{pcsha}^{-1}$ (BEL-Ql) with 2150 pcsha $^{-1}$ on the NFS; Dg from 2.9 (BEL-Ns) to $19.1 \mathrm{~cm}$ (PIAS-QsNc) and $16.7 \mathrm{~cm}$ on the NFS; G from 4.1 (BEL-Ns) to $36.6 \mathrm{~m}^{2} \mathrm{ha}^{-1}$ (PIAS-Qs) and $35.7 \mathrm{~m}^{2} \mathrm{ha}^{-1}$ on the NFS; H100 from 4.4 (BEL-Ns) to $17.9 \mathrm{~m}$ (PIAS-QsNc) and $18.5 \mathrm{~m}$ on the NFS and SDI from 203.1 (BEL-Ns) to 894.3 (PIAS-Qs) and 1127.4 on the NFS (Table 2). The RMS sites with the greatest similarity to the NFS dendrometric characteristics were the Piaseczno S mining external slope (PIAS-Qs and PIAS-QsNs) and Smolnica coal mining spoil heap (SMOL-Cf), all of which were the same age as the NFS control stands.

Needle biometric parameters

Needle characteristics may provide better diagnostic criteria for site assessment than dendrometric measurements, which can be highly subject to variations in stand age. The needle biomass $\left(\mathrm{DM}_{100 n}\right)$ on RMS sites ranged from 1.75 (SMOL-Cf) to $3.47 \mathrm{~g}$ (SCZ-Qs). The NFS $\mathrm{DM}_{100 n}$ was $3.53 \mathrm{~g}$, which is slightly higher than all of the RMS sites, but only the SMOL-Cf and PIASQs RMS had significantly lower (at $P=0.05$ ) needle biomass (Table 3$)$. The needle length $\left(L_{300 n}\right)$ ranged from 42.3 (SCZ-Qs) to $56.8 \mathrm{~mm}$ (PIAS-QsNc). Again,

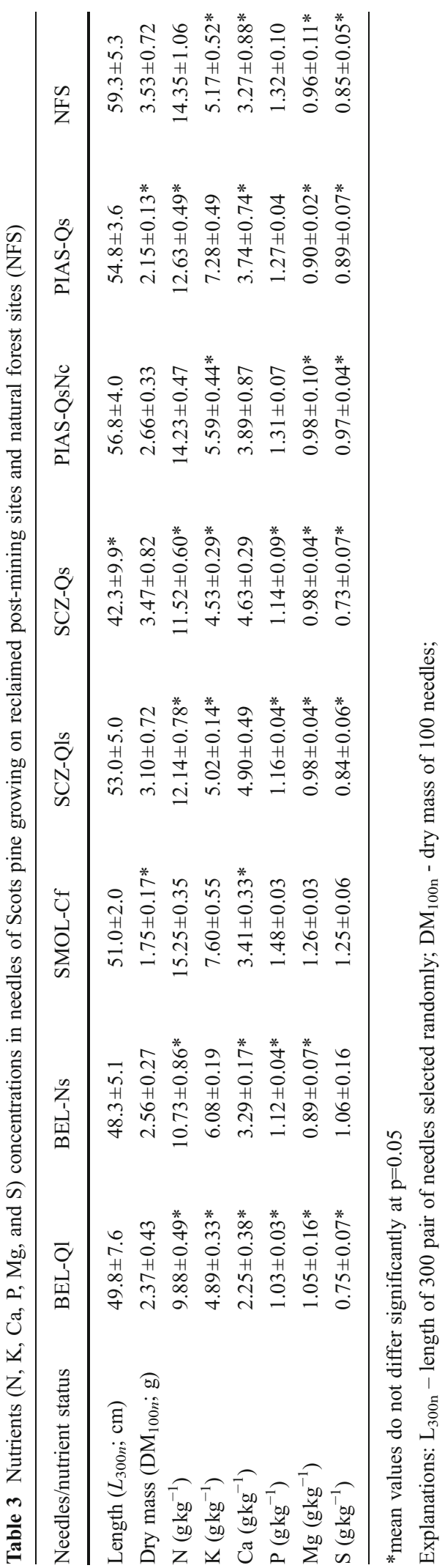


the NFS control had a slightly higher $L_{300 n}$ value $(59.3 \mathrm{~mm})$ than the RMS sites although only SCZQs was significantly lower (at $P=0.05$ ) (Table 3 ).

Needle nutrients and relationships

The needle $\mathrm{N}$ and $\mathrm{P}$ contents had the greatest deviation from the nutrient content found in the NFS needles, while $\mathrm{Mg}$ and $\mathrm{S}$ contents in the needles were the most likely to be similar to needle contents in NFS. The needle $\mathrm{N}$ content for the RMS ranged from: 9.88 (BEL-Ql) to $15.25 \mathrm{~g} \mathrm{~kg}^{-1}$ (SMOL-Cf) with $14.35 \mathrm{~g}$ $\mathrm{kg}^{-1}$ found on the NFS. Excluding SMOL-Cf and PIAS-QsNc, needle $\mathrm{N}$ contents on RMS sites were significantly lower (at $P=0.05$ ) than the NFS (Table 3). Needle P was also significantly lower (at $P=0.05)$ in the RMS needles which ranged from 1.03 (BEL-Q1) to $1.48 \mathrm{~g} \mathrm{~kg}^{-1}$ (SMOL-Cf), with the exception of SMOL-Cf, PIAS-QsNc, and PIAS-Qs which were statistically similar to the NFS needle P content of $1.32 \mathrm{~g} \mathrm{~kg}^{-1}$. Contrarily, the needle $\mathrm{Mg}$ content in the NFS needles $\left(0.96 \mathrm{~g} \mathrm{~kg}^{-1}\right)$ was statistically similar (at $P=0.05$ ) to needle $\mathrm{Mg}$ content on RMS sites (with the exception of SMOL-Cf), with a range of 0.89 (BEL$\mathrm{Ns}$ ) to $1.26 \mathrm{~g} \mathrm{~kg}^{-1}$ (SMOL-Cf). Similarly, needle $\mathrm{S}$ contents on RMS (range of 0.73 (SCZ-Qs) to $1.25 \mathrm{~g}$ $\mathrm{kg}^{-1}$ (SMOL-Cf)) and NFS $\left(0.85 \mathrm{gkg}^{-1}\right)$ were statistically similar (at $P=0.05$ ) with the exception of BELNs and SMOL-Cf which had slightly higher levels of needle S (Table 3).

Needle nutrient ratios

The nutrient ratios in the needles on RMS sites confirm a general deficiency of nutrients compared with the NFS control (Table 4). The RMS needle N/P ratio ranged from 9.6 (BEL-Q1 and BEL-Ns) to 10.9 (PIAS-
QsNc) with all but PIAS-QsNc and SCZ-Qls significantly lower (at $P=0.05$ ) than the NFS needle N/P ratio of 10.9 (Table 4 ). The needle $\mathrm{N} / \mathrm{K}$ ratio was likewise significantly lower than the NFS (2.8) at BEL-Q1 (2.0), BEL-Ns (1.8), SMOL-Cf (2.0), and PIAS-Qs (1.7) (Table 4). The needle N/Ca ratios were statistically similar for the RMS and NFS sites with the exception that both RMS sites at Szczakowa had slightly lower $\mathrm{N} / \mathrm{Ca}$ ratios. The needle $\mathrm{N} / \mathrm{Mg}$ ratio was again significantly higher in NFS needles than RMS needles with a range from 9.5 (BEL-Q1) to 14.6 (PIAS-Qs-Nc) and 15.0 for NFS. Only the needles from the Piaseczno sites were statistically similar to the NFS.

The needle $\mathrm{K} / \mathrm{Ca}, \mathrm{K} / \mathrm{Mg}$, and $\mathrm{Ca} / \mathrm{Mg}$ ratios were much more comparable to the NFS needle ratios. The $\mathrm{K} / \mathrm{Ca}$ ratio of the NFS needles was 1.7 and only the Szczakowa sites (1.0) were significantly lower $(P=$ $0.05)$. The $\mathrm{K} / \mathrm{Mg}$ ratio was significantly higher on the Piaseczno S mine external heap (8.1) than the NSF (5.4) but otherwise there was little change in the $\mathrm{K} / \mathrm{Mg}$ ratio between the NFS and the RMS needles. There were no significant differences in the $\mathrm{Ca} / \mathrm{Mg}$ ratios of the RMS and NFS needles.

\section{Discussion}

Previous studies on coal spoils in Lusatia, Germany, have assigned soil fertility ratings to Scots pine (Heinsdorf 1999). Accordingly, the RMS at SMOLCf, SCZ-Qls, PIAS-QsNc, and PIAS-Qs have low N levels and BEL-Q1, BEL-Ns, and SCZ-Qs have very low $\mathrm{N}$ levels. The range of needle $\mathrm{N}$ for the RMS and NFS control was low compared with a needle $\mathrm{N}$ range of $11.7-29.1 \mathrm{~g} \mathrm{~kg}^{-1}$ for pines in the same climatic zone (Fober 1993). RMS are often deficient in N (Li and
Table 4 Nutrient (N, K, Ca, P, $\mathrm{Mg}$, and $\mathrm{S}$ ) ratios (by weight concentration in dry mass) of Scots pine needles grown on reclaimed mine soils (RMS) and natural forest sites (NFS)

*mean values do not differ significantly at $\mathrm{p}=0.05$

\begin{tabular}{lllllllrr}
\hline $\begin{array}{l}\text { Nutrient } \\
\text { ratio }\end{array}$ & $\begin{array}{l}\text { BEL- } \\
\text { Q1 }\end{array}$ & $\begin{array}{l}\text { BEL- } \\
\text { Ns }\end{array}$ & $\begin{array}{l}\text { SMOL- } \\
\text { Cf }\end{array}$ & $\begin{array}{l}\text { SCZ- } \\
\text { Qls }\end{array}$ & $\begin{array}{l}\text { SCZ- } \\
\text { Qs }\end{array}$ & $\begin{array}{l}\text { PIAS- } \\
\text { QsNc }\end{array}$ & $\begin{array}{l}\text { PIAS- } \\
\text { Qs }\end{array}$ & NFS \\
\hline $\mathrm{N} / \mathrm{P}$ & $9.6^{*}$ & $9.6^{*}$ & $10.3^{*}$ & 10.5 & $10.1^{*}$ & 10.9 & $10.0^{*}$ & 10.9 \\
$\mathrm{~N} / \mathrm{K}$ & $2.0^{*}$ & $1.8^{*}$ & $2.0^{*}$ & 2.4 & 2.6 & 2.6 & $1.7^{*}$ & 2.8 \\
$\mathrm{~N} / \mathrm{Ca}$ & 4.5 & 3.3 & 4.5 & $2.5^{*}$ & $2.5^{*}$ & 3.8 & 3.5 & 4.6 \\
$\mathrm{~N} / \mathrm{Mg}$ & $9.5^{*}$ & $12.1^{*}$ & $12.1^{*}$ & $12.4^{*}$ & $11.8^{*}$ & 14.6 & 14.0 & 15.0 \\
$\mathrm{~K} / \mathrm{Ca}$ & 2.2 & 1.9 & 2.2 & $1.0^{*}$ & $1.0^{*}$ & 1.5 & 2.0 & 1.7 \\
$\mathrm{~K} / \mathrm{Mg}$ & 4.7 & 6.8 & 6.0 & 5.1 & $4.6^{*}$ & 5.7 & 8.1 & 5.4 \\
$\mathrm{Ca} / \mathrm{Mg}$ & $2.2^{*}$ & $3.7^{*}$ & $2.8^{*}$ & $5.0^{*}$ & $4.7^{*}$ & $3.9^{*}$ & $4.1^{*}$ & $3.5^{*}$ \\
\hline
\end{tabular}


Fig. 1 Range of $\mathrm{N}$ content in the needles and the rating for Scots pine (P. sylvestris): 1 high, 2 medium, and 3 low

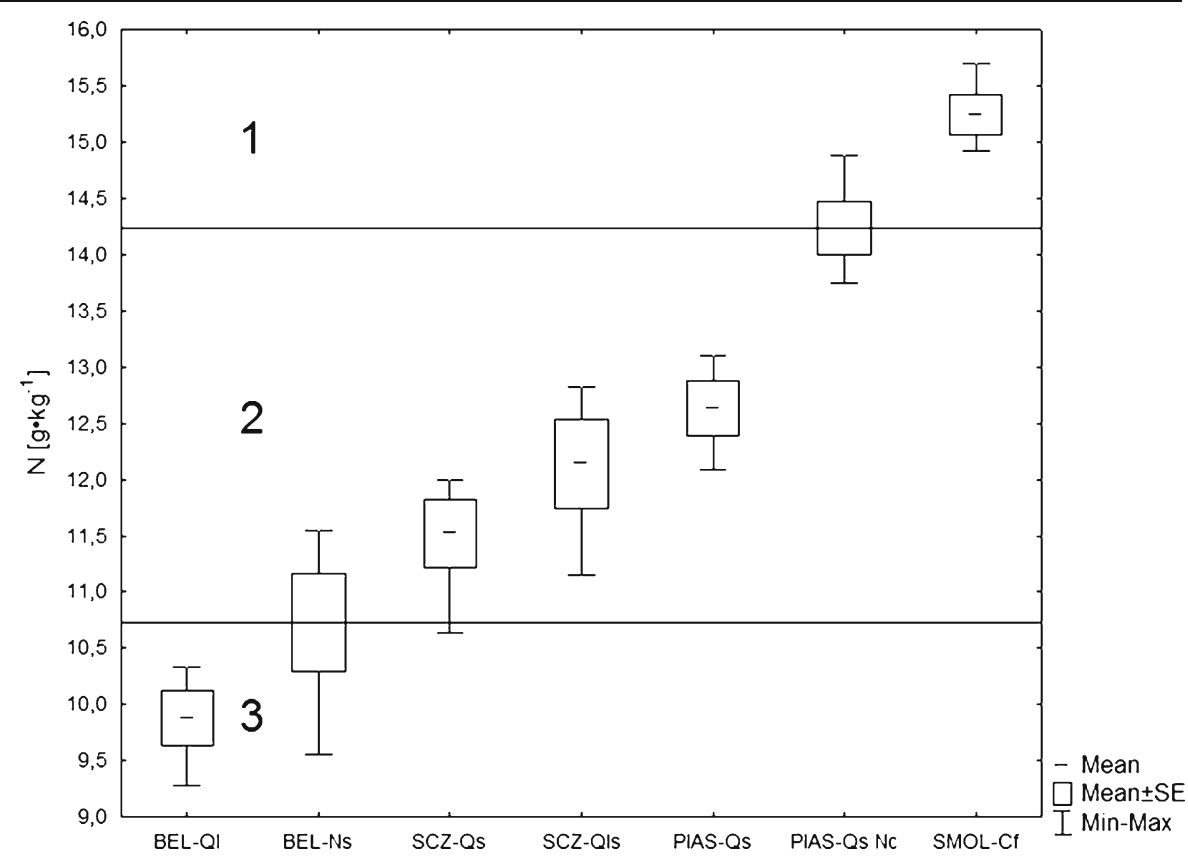

Daniels 1994), which is frequently a limiting factor for tree growth. Despite the low content of $\mathrm{N}$ in the soils and needles of this study, no clear visual indications of $\mathrm{N}$ deficiency, such as chlorosis were reported. $\mathrm{P}$ is also a deficient nutrient in the majority of RMS (Marrs and Bradshaw 1993). In this study however, the P content in RMS at BEL-Q1, BEL-Ns, SCZ-Q1s, and SCZ-Qs was medium and even high at SMOL-Cf, PIAS-QsNc, and PIAS-Qs (according to the above-mentioned fertility ratings at Lusatia, i.e., Germany). As a result, the needle $\mathrm{P}$ in this study was given a medium rating in comparison to a natural needle $\mathrm{P}$ range of $0.3-5.2 \mathrm{~g}$ $\mathrm{kg}^{-1}$ (Fober 1993). S, on the other hand, was low at BEL-Ns, and at SMOL-Cf, and found to be very low at BEL-Q1, SCZ-Q1s, SCZ-Qs, PIAS-QsNc, and PIAS-Qs (Heinsdorf 1999). Such low S content in the needles of pines growing in areas heavily impacted by numerous coal-burning power plants and other industries is surprising. It is possible that the low needle $\mathrm{S}$ is a symptom of lower $\mathrm{SO}_{x}$ emissions which have reduced atmospheric $\mathrm{S}$ deposition in this part of Europe. The reduction of S emissions from coal combustion in power plants is primarily the result of the installation of flu gas desulphurization technologies (Klose et al. 2003). However, low needle $\mathrm{S}$ in the trees grown on RMS with sufficient to high levels of soil $\mathrm{S}$ may indicate inhibited uptake. The speciation of elements found in soils depends on geochemical and thermodynamic conditions such as element concentrations, $\mathrm{pH}$, and sorption complex. In RMS, these relationships are not yet stable and may be frequently disturbed which can affect the availability of nutrients

Table 5 The results of comparison of the nitrogen content in pine needles from reclaimed mine soils by RIR Tukey's test

\begin{tabular}{llllllrr}
\hline & BEL-Q1 & BEL-Ns & SCZ-Qs & SCZ-Q1s & PIAS-Qs & PIAS-Qs Nc & SMOL-Cf \\
\hline BEL-Q1 & & $0.453358^{*}$ & $0.014069^{*}$ & $0.000633^{*}$ & $0.000182^{*}$ & $0.000155^{*}$ & $0.000155^{*}$ \\
BEL-Ns & 0.453358 & & 0.526148 & $0.043353^{*}$ & $0.003527^{*}$ & $0.000155^{*}$ & $0.000155^{*}$ \\
SCZ-Qs & $0.014069^{*}$ & 0.526148 & & 0.763465 & 0.174386 & $0.000188^{*}$ & $0.000155^{*}$ \\
SCZ-Qls & $0.000633^{*}$ & $0.043353^{*}$ & 0.763465 & & 0.906775 & $0.001383^{*}$ & $0.000158^{*}$ \\
PIAS-Qs & $0.000182^{*}$ & $0.003527^{*}$ & 0.174386 & 0.906775 & & $0.016915^{*}$ & $0.000214^{*}$ \\
PIAS-Qs Nc & $0.000155^{*}$ & $0.000155^{*}$ & $0.000188^{*}$ & $0.001383^{*}$ & $0.016915^{*}$ & 0.255442 \\
SMOL-Cf & $0.000155^{*}$ & $0.000155^{*}$ & $0.000155^{*}$ & $0.000158^{*}$ & $0.000214^{*}$ & 0.255442 & \\
\hline
\end{tabular}

$* P=0.05$, significant difference 
Table 6 Statistical grouping of reclaimed mine soils according to the nitrogen content in the pine needles

\begin{tabular}{lccccc}
\hline Soil-substrate variant & \multicolumn{4}{c}{ Mean for variant $\left(\mathrm{gkg}^{-1}\right)$} \\
\hline BEL-Q1 & 9.88 & $-* * *$ & & & \\
BEL-Ns & $10.73^{\mathrm{a}}$ & $-* * *$ & $-* * *$ & & \\
SCZ-Qs & 11.52 & & $-* * *$ & $-* * *$ & \\
SCZ-Q1s & 12.14 & & & $-* * *$ & \\
PIAS-Qs & 12.63 & & & $-* * *$ & \\
PIAS-Qs Nc & $14.23^{\mathrm{a}}$ & & & & $-* * *$ \\
SMOL-Cf & 15.25 & & & & $-* * *$ \\
\end{tabular}

${ }^{\mathrm{a}}$ Mean values for groups used as the ranges for nitrogen rating

uptake (Katzur and Haubold-Rosar 1996; Heinsdorf 1999; Knoche et. al. 2002; Pietrzykowski 2010a). Such is likely the case with the low needled $\mathrm{S}$ in the "sulfurized soils" of Bełchatów (BEL-Ns) and Smolnica (SMOL-Cf) where high soil S is likely not found in the form of plant available sulfate. The remaining macronutrients $\mathrm{K}, \mathrm{Ca}$, and $\mathrm{Mg}$ were at sufficient or higher levels for all RMS sites (Heinsdorf 1999).

It should be stressed that the soils and the reclamation technologies, in particular, that were applied in this study differed significantly from the conditions found at the Lusatia coal spoil heaps where the above-mentioned fertility ratings were derived. In Lusatia, soils were intensively fertilized by the addition of as much as $160 \mathrm{Mg}$ $\mathrm{ha}^{-1}$ of lignite ash (Katzur and Hauboldt-Rosar 1996). Presently, the only reclaimed soils fertilized are those that are considered severely deficient in nutrients. Intensive fertilization of soils, a former reclamation practice, has been phased out because maximizing tree growth is no longer considered the chief aim (Knoche et al. 2002).

It is crucial that a balanced supply of macronutrients exist in RMS which usually necessitates fertilization
(Knoche et. al. 2002; Pietrzykowski 2010a). Prior to fertilization, the relationship of macronutrients in a stable ecosystem must be defined (Baule and Fricker 1970). The balanced soil macronutrient content will, in turn, affect the supply and quantity of macronutrients in needles as well as the health (physiologic functioning) and stability of the tree stand (Baule and Fricker 1970). Macronutrients in the tree biomass display a certain natural variability, and therefore it is inappropriate to define precise quantitative relations. However, a comparison of results from mine sites and control plots on NFS (Table 3) shows that macronutrient ratios in biomass have been disturbed at mine sites, particularly the relationship of $\mathrm{N}$ to other nutrients. The nutrient imbalance shows that conditions in reclaimed soils are completely different from natural sites, necessitating the adaptation of a "tree-nutrient strategy" (Hüttl 1998; Pietrzykowski 2010a). As previously mentioned, although no negative symptoms in tree growth have been found, imbalanced nutrient supply may lead to physiological and growth problems in the future (Baule and Fricker 1970). Recently, tree stands in the Lusatian Mine District suffered significant damage due to infections from the pathogen Heterobasidion annosum (Fr.) Bref. after the RMS had been intensively fertilized and ameliorated with ash (Knoche and Ertle 2010).

During the initial phase of the reclamation treatment in this study, a range of nutrient fertilizations were applied, including: $\mathrm{N}$ from 60 (BEL-Q1, BEL-Ns) to $140 \mathrm{kgha}^{-1}$ (SCZ-Qs, SCZ-Qls), P from 20 (SMOLCf) to $130 \mathrm{kgha}^{-1}$ (SCZ-Qs, SCZ-Qls), and $\mathrm{K}$ from 20 (SMOL-Cf) to $150 \mathrm{kgha}^{-1}$ (SCZ-Qs and SCZ-Qls) (Table 1). The different nutrient additions, apart from substrate qualities, can significantly impact the growth of woody materials during the earlier years of tree growth. It is assumed that "one-off" fertilization can

Table 7 The results of comparison of the phosphorus content in pine needles from reclaimed mine soils by RIR Tukey's test

\begin{tabular}{llllllrr}
\hline & BEL-Q1 & BEL-Ns & SCZ-Qs & SCZ-Q1s & PIAS-Qs & PIAS-Qs Nc & SMOL-Cf \\
\hline BEL-Q1 & & 0.247361 & 0.059713 & $0.027665^{*}$ & $0.000185^{*}$ & $0.000156^{*}$ & $0.000155^{*}$ \\
BEL-Ns & 0.247361 & & 0.985881 & 0.910605 & $0.009954^{*}$ & $0.000986^{*}$ & $0.000155^{*}$ \\
SCZ-Qs & 0.059713 & 0.985881 & & 0.999769 & 0.052089 & $0.005102^{*}$ & $0.000155^{*}$ \\
SCZ-Qls & $0.027665^{*}$ & 0.910605 & 0.999769 & & 0.108023 & $0.011544^{*}$ & $0.000155^{*}$ \\
PIAS-Qs & $0.000185^{*}$ & $0.009954^{*}$ & 0.052089 & 0.108023 & & 0.931220 & $0.000364 *$ \\
PIAS-Qs Nc & $0.000156^{*}$ & $0.000986^{*}$ & $0.005102^{*}$ & $0.011544^{*}$ & 0.931220 & $0.002832^{*}$ \\
SMOL-Cf & $0.000155^{*}$ & $0.000155^{*}$ & $0.000155^{*}$ & $0.000155^{*}$ & $0.000364^{*}$ & $0.002832^{*}$ & \\
\hline
\end{tabular}

$* P=0.05$, significant difference by RIR Tukey’s test 
Table 8 Statistical grouping of reclaimed mine soils according to the phosphorus content in the pine needles

\begin{tabular}{lllllll}
\hline Soil-substrate variants & \multicolumn{5}{c}{ Mean for variant $\left(\mathrm{gkg}^{-1}\right)$} \\
\hline BEL-Q1 & 1.03 & $-* * *$ & & & \\
BEL-Ns & 1.12 & $-* * *$ & $-* * *$ & & \\
SCZ-Qs & $1.14^{\mathrm{a}}$ & $-* * *$ & $-* * *$ & $-* * *$ & & \\
SCZ-Q1s & 1.16 & & $-* * *$ & $-* * *$ & \\
PIAS-Qs & 1.27 & & & $-* * *$ & $-* * *$ & \\
PIAS-Qs Nc & 1.31 & & & & $-* * *$ & \\
SMOL-Cf & $1.48^{\mathrm{a}}$ & & & & $-* * *$
\end{tabular}

${ }^{\mathrm{a}}$ Mean values for groups used as the ranges for phosphorus rating

cause Scots pine growth to outdistance unfertilized sites in 2 or 3 years (Baule and Fricker 1970). However, in this study, the impact of the initial $\mathrm{N}$ fertilization has not been observed in the nutrient content of the tree biomass after more than 10 years. At the Bełchatów spoil heap (BEL-Q1 and BEL-Ns), the lowest application of $\mathrm{N}$ (Table 1) corresponded with a $\mathrm{N}$ deficiency (Fig. 1), while at the Szczakowa sand mining pit (SCZ-Qs and SCZ-Qls), the highest rate of $\mathrm{N}$ has not had any significant effect. Thus, we conjecture that the long-term effects of fertilization depend more on the qualities of the soil, especially the quantity of the clay sized fraction and the TEB, than on the initial applications of $\mathrm{N}$. The effects of mineral fertilization on RMS may be improved by combining them with phytoameliorative plant cultivation (papilionaceous plants such as lupin (Lupinus luteus L.)) (Heinsdorf 1999). In the majority of the mine sites investigated in this study, the cultivation of grass and papilionaceous plants (BEL-Q1, BEL-Ns, PIAS-Qs, and PIAS-QsNc), or lupin only (SCZ-Qs and SCZ-Ols), were used as biologic fertilization (Table 1).

In this study, tree growth significantly correlated with $\mathrm{N}(R=0.70$ for $\mathrm{Dg}$ and $R=0.66$ for $\mathrm{H} 100)$ and $\mathrm{P}$ contents ( $R=0.59$ for $\mathrm{Dg}$ and $R=0.55$ for H100). Forestry management often assesses the productivity of a site by measuring the height of the dominant and codominant tree species to determine the site index (SI). Ideally, the average heights of various evenly aged tree stands are measured to determine species-specific SI models (Monserud et al. 1990). SI is dependent on tree species, stand density, soil, and forest habitat thereby providing valuable information about the economy and stability of tree stands that aid in determining the management strategies on afforested mine sites (Heinsdorf 1996; Torbert and Burger 2000). However, this approach is restricted to even-aged monocultures (e.g., Vanclay 1994). In the Appalachian Mine District (USA), SI is applied to define the potential productivity of White pine (Pinus strobus) plantations (Torbert et al. 1990; Torbert and Burger 2000). In the cited studies, a significant correlation was
Fig. 2 Range of $\mathrm{P}$ content in the needles and the rating for Scots pine ( $P$. sylvestris): 1 high, 2 medium, and 3 low

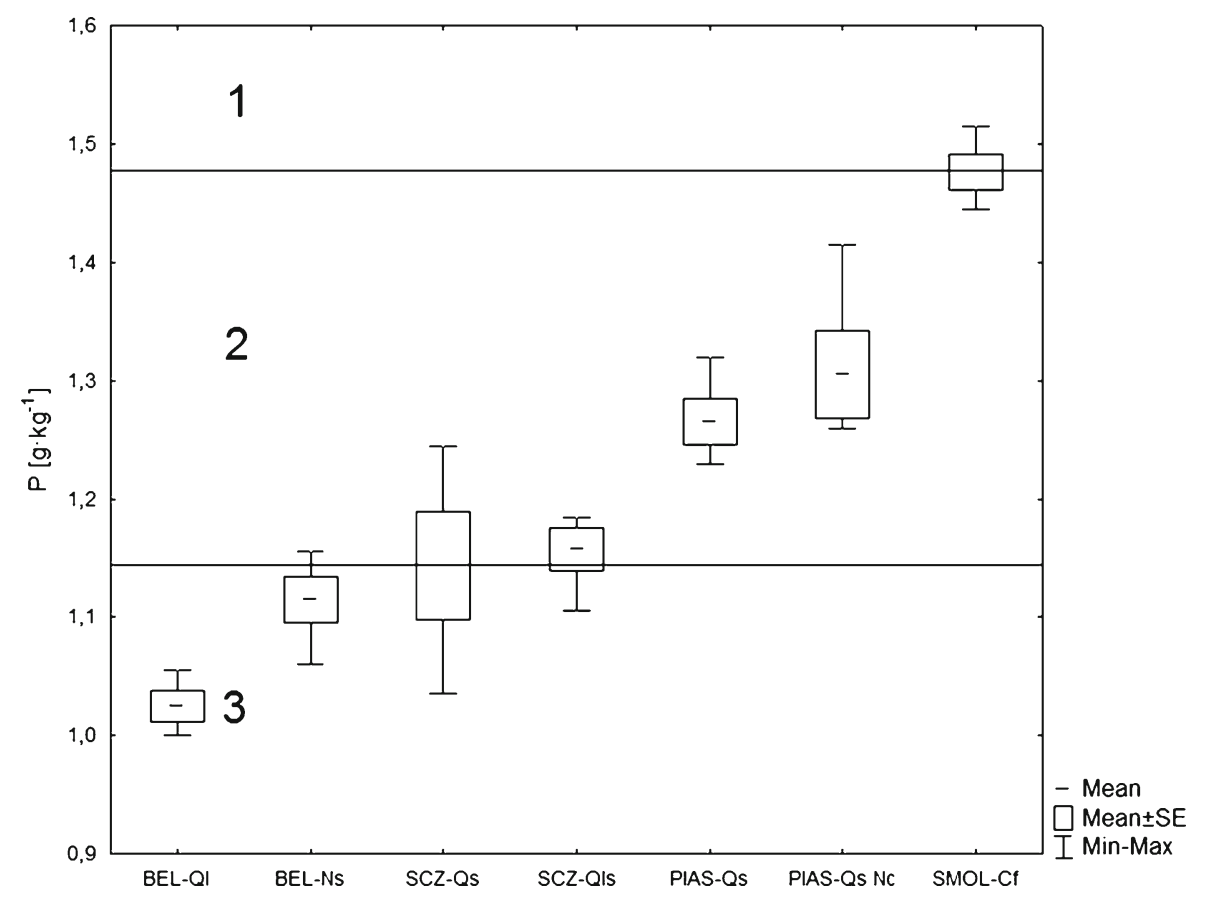


found between SI, electrical conductivity (by soil solution extract) and the content of available forms of $\mathrm{P}$ and $\mathrm{K}$ (deficient elements in the soils of the Appalachian region) (Torbert et al. 1990). However, growth features were largely dependent on tree stand age. Moreover, there was an important correlation with the $\mathrm{N}$ and $\mathrm{P}$ content ( $R=0.41$ and $R=0.36$, respectively) and needle length $\left(L_{300 n}\right)$, which in turn positively correlated with tree growth characteristics $(\mathrm{Dg}, R=0.44$ and $\mathrm{H} 100$, $R=0.50$, respectively). Based on these findings, the $L_{300 n}$ can be used as a simplified trophic condition assessment index for Scots pine on mine sites. The trophic rating and corresponding $L_{300 n}$ range for this study are: (1) high $\left(L_{300 \mathrm{n}}>57.0 \mathrm{~mm}\right)$, (2) medium $\left(L_{300 n}\right.$ from 42.0 to $57.0 \mathrm{~mm})$, and (3) low $\left(L_{300 n}<42 \mathrm{~mm}\right)$.

The basis for a full description of nutrition is formed, however, by the range of nutrient content in the needles (Heinsdorf 1999). The mean nutrient contents of the needles were used to statistical group (homogenous) RMS (RIR-Tukey at $P=0.05$ ) for $\mathrm{N}$ and $\mathrm{P}$ (for $\mathrm{N}$, see Tables 5 and 6; for P, see Tables 7 and 8). Nutrient ratings were proposed from the mean values of extreme groups belonging to a homogeneous data set (Table 7 for $\mathrm{N}$ content and Table 8 for $\mathrm{P}$ content). The nutrient rating for $\mathrm{N}$ was: (1) high $\left(\mathrm{N}>14.23 \mathrm{~g} \mathrm{~kg}^{-1}\right)$, (2) medium (N from 10.73 to $\left.14.23 \mathrm{~g} \mathrm{~kg}^{-1}\right)$, and (3) low $(N<$ $\left.10.73 \mathrm{~g} \mathrm{~kg}^{-1}\right)$ (Fig. 1). The nutrient rating for $\mathrm{P}$ was: (1) high $\left(P>1.48 \mathrm{~g} \mathrm{~kg}^{-1}\right),(2)$ medium (P from 1.14 to $\left.1.48 \mathrm{gkg}^{-1}\right)$, and (3) low $\left(P<1.14 \mathrm{gkg}^{-1}\right)$ (Fig. 2).

\section{Conclusions}

Pine trees grown on fertilized RMS at the Smolnica spoil heap (SMOL-Cf) were found to have the highest level of nutrients whereas those grown on the Bełchatów spoil heap (BEL-Q1) had the lowest nutrient levels. The soil substrate exerted the greatest influence on the uptake of macronutrients in tree biomass. The results of fertilization (especially $\mathrm{N}$ ) carried out during the initial reclamation process were not evident after about 12 years. The most deficient nutrients in the soil were $\mathrm{N}$ and $\mathrm{P}$, which is in accordance with the literature for other RMS. However, no distinct symptoms to indicate nutrient deficiency in trees were found. The soil fertility ratings for pine trees grown in the waste dumps of the Lusatian Mine District and in NFS should only be treated as approximate. This is due to the fact that each post-mining site is specific, and moreover, that the Scots pine has a large adaptation capability. In case of $\mathrm{N}$ and $\mathrm{P}$, appropriate soil levels and degrees of nutrient supply for pines were defined for specific RMS in this study. These ratings may be applied to assess the fertilization requirements in the investigated RMS.

Acknowledgments This study was financially supported by the Polish Ministry of Science and Higher Education Grant No. 309 $01332 / 2076$ and partly by statutory financial support of the Ministry of Science and Higher Education RP (DS-3420 in 2012, Department of Forest Ecology University of Agriculture in Krakow). This paper was developed during the 60th anniversary of the University of Agriculture in Krakow, Poland.

Open Access This article is distributed under the terms of the Creative Commons Attribution License which permits any use, distribution, and reproduction in any medium, provided the original author(s) and the source are credited.

\section{References}

Ballard, T. M., \& Carter, R. E. (1986). Evaluating forest stand nutrient status. Land Management Report No. 20. Victoria: Ministry of Forests.

Baule, H., \& Fricker, C. (1970). The fertilizer treatment of forest trees. Munich: BLV-Verlagsges.

Baumann, K., Rumpelt, A., Schneider, B. U., Marschner, P., Hüttl, R. F., et al. (2006). Seedling biomass and element content of Pinus sylvestris and Pinus nigra grown in sandy substrates with lignite. Geoderma, 136, 573-578.

Bendtfeldt, E. S., Burger, J. A., Daniels, W. L., et al. (2001). Quality of amended mine soils after sixteen years. Soil Science Society of America Journal, 65, 1736-1744.

Bradshaw, A. D. (1983). The reconstruction of ecosystems. Journal of Applied Ecology, 20, 1-17.

Bradshow, A. D., \& Chadwick, M. J. (1980). The restoration of Land. The ecology and reclamation of derelict and degraded land. Oxford: Blackwell.

Bradshaw, A. D., \& Hüttl, R. F. (2001). Future mine site restoration involves a broader approach. Ecological Engineering, 17(2-3), 87-90.

Braekke, F. H., \& Sahin, N. (2002). Reliability of foliar analyses of Norway spruce stands in a Nordic gradient. Silva Fennica, 36(2), 489-504.

Chambers, J. C., Brown, R. W., Williams, B. D., et al. (1994). An evaluation of reclamation success on Idaho's phosphate mines. Restoration Ecology, 2, 4-16.

Chodak, M., \& Niklińska, M. (2010). The effect of different tree species on the chemical and microbial properties of reclaimed mine soils. Biology and Fertility of Soils, 46(6), 555-566.

Daniels, W.L., Genthner, M.H., Hodges, R.L., et al. 1992. Soil development in sandy tailings derived from mineral sands mining in Florida. In Proceedings of the 9th National Meeting of the American Society for Surface Mining and Reclamation, Duluth, 14-18 June 1992, ASSMR, Lexington, pp. 37-47.

De Vos, B., Van Meirvenne, M., Quataert, P., Deckers, J., Muys, B., et al. (2005). Predictive Quality of pedotransfer 
functions for estimating bulk density of forest soils, division S-7-forest, range and wildland soils. Soil Science of America Journal, 69, 500-510.

Dutta, R. K., \& Agrawal, M. (2003). Restoration of opencast coal mine spoil by planting exotic tree species: a case study in dry tropical region. Ecological Engineering, 21, 143-151.

Farjon, A (2005) Pines: drawings and descriptions of the genus Pinus, 2nd revised edition. Leiden: Brill Academic Publishers.

Filcheva, E., Noustorova, M., Gentcheva-Kostadinova, S., Haigh, M. J., et al. (2000). Organic accumulation and microbial action in surface coal mine spoils, Pernik, Bulgaria. Ecological Engineering, 15, 1-15.

Fober, H (1993) Nutrient supply. In S. Białobok, A. Boratyński, W. Bugała (Eds.), Scots pine biology (pp. 182-193). The Institute of Dendrology, Polish Academy of Sciences. Poznań-Kórnik: Sorous Press. (in Polish).

Golley, F. B. (1993). History of the ecosystem concept in ecology. New Haven: Yale University Press.

Heinsdorf, D. (1996). Development of forest stands in the Lusatian Lignite Mining District after mineral fertilization adopted to site and tree species. Water, Air, and Soil Pollution, 91, 33-42.

Heinsdorf, D. (1999). Düngung von Forstkulturen auf Lausitzer Kippen. Eberswalde: Laubag.

Hüttl, R. F. (1998). Ecology of post strip-mining landscapes in Lusatia, Germany. Environmental Science and Policy, 1, 129-135.

Hüttl, R. F., \& Weber, E. (2001). Forest ecosystem development in post-mining landscapes, a case study of the Lusatian lignite district. Naturwissenschaften, 88, 322329.

Howard, J. L., Amos, D. F., Daniels, W. L., et al. (1988). Phosphorous and potassium relationships in southwestern Virginia coal-mine spoils. Journal of Environmental Quality, 17, 695-700.

IUSS Working Group WRB. (2006). World Reference Base for Soil Resources. World Soil Resources Reports No. 103. Rome: FAO.

Kaar, E. (2002). Coniferous trees on exhausted oil shale opencast mines. Metsanduslikud Uurimused (Forestry Studies), 36, 120-125.

Katzur, J., \& Haubold-Rosar, M. (1996). Amelioration and reforestation of sulfurous mine soils in Lusatia (Eastern Germany). Water, Air, and Soil Pollution, 91, 17-32.

Klose, S., Tölle, R., Bäucker, E., Makeschin, F., et al. (2003). Stratigraphic Distribution of lignite-derived atmospheric deposits in forest soils of the upper Lusatian Region, East Germany. Water, Air, and Soil Pollution, 142(1-4), 3-25.

Knoche, D., \& Ertle, C. (2010). Infection of Scots pine afforestations (Pinus sylvestris L.) by annosum root rot (Heterobasidion annosum (Fr.) Bref.) in the Eastern German Lignite District. Civil and Environmental Engineering Reports, 4, 35-45.

Knoche, D., Embacher, A., Katzur, J., et al. (2002). Water and element fluxes of red oak ecosystems during stand development on post-mining sites (Lusatian Lignite District). Water, Air, and Soil Pollution, 141, 219-231.

Krzaklewski W. 2001. Reclamation of post-mining and postindustrial areas, in: Kotarba M.J. (Eds.), Alteration of the environment and sustainable development (pp. 85-104). Krakow: TBPŚ Geosfera. (in Polish).
Kuznetsova, T., Mandre, M., Klõšeiko, J., Pärn, H., et al. (2010). A comparison of the growth of Scots pine (Pinus sylvestris L.) in a reclaimed oil shale post-mining area and in a Calluna site in Estonia. Environmental Monitoring and Assessment, 166, 257-265.

Marrs, R., \& Bradshaw, A. D. (1993). Primary succession on man-made wastes: The importance of resource acquisition. In J. Miles \& D. W. H. Walton (Eds.), Primary succession of land (pp. 221-247). Oxford: Blackwell.

Monserud, R. A., Moody, U., \& Breuer, D. W. (1990). A soilsite study for inland Douglas-fir. Canadian Journal of Forest Research, 20, 686-695.

Li, R. S., \& Daniels, W. L. (1994). Nitrogen accumulation and form over time in young mine soils. Journal of Environmental Quality, 23, 166-172.

Ochał, W., Pająk, M., Pietrzykowski, M., et al. (2010). Diameter structure of selected pine stands growing on post-mining sites reclaimed for forestry (in Polish, English summary). Sylwan, 154(5), 323-332.

Ostrowska, S., Gawlinski, Z., Szczubialka, Z., et al. (1991). Procedures for soil and plants analysis (in Polish). Warsaw: Institute of Environmental Protection.

Parrotta, J. A., Turnbull, J. W., Jones, N., et al. (1997). Catalyzing native forest regeneration on degraded tropical lands. Forest Ecology and Management, 99, $1-7$.

Pietrzykowski, M. (2010a). Scots pine (Pinus sylvestris L.) ecosystem macronutrients budget on reclaimed mine sites-stand trees supply and stability. Natural Science, 2 (6), 590-599.

Pietrzykowski, M (2010b) Soil characteristic, and macro-nutrients accumulation and relationships in soil and phytocenosis as the criterion to forest land reclamation assessment. In: M. Pietrzykowski (Ed.), An analysis and optimisation of site classification methods and criteria for the evaluation of reclaim to forest on selected post mining areas in Poland (pp. 65-84). Krakow: University of Agriculture in Krakow Press. (in Polish, English summary).

Pietrzykowski, M., \& Krzaklewski, W. (2007). An assessment of energy efficiency in reclamation to forest. Ecological Engineering, 30, 341-348.

Pietrzykowski, M., \& Socha, J. (2011). An estimation of Scots pine (Pinus sylvestris L.) ecosystem productivity on reclaimed post-mining sites in Poland (central Europe) using of allometric equations. Ecological Engineering, 37 (2), 381-386.

Rodrigue, J. A., Burger, J. A., Oderwald, R. G., et al. (2002). Forest productivity and commercial value of pre-law reclaimed mined land in the eastern United States. Northern Journal of Applied Forestry, 19(3), 106-114.

Schaaf, W. (2001). What can element budgets of false-time series tell us about ecosystem development on postlignite mining sites? Ecological Engineering, 17(2-3), 241-252.

Shaw, J. D. (2000). Application of stand density index to irregularly structured stands. Western Journal of Applied Forestry, 15, 40-42.

Singh, A. N., Raghubanshi, A. S., Singh, J. S., et al. (2002). Plantations as a tool for mine spoil restoration. Current Science, 82, 1436-1441. 
Inc, S. S. (2007). Electronic statistics textbook (version electronic). Tulsa: Statsoft.

Torbert, J. L., \& Burger, J.A (2000) Forest land reclamation, in: J. Bartels (Eds.), Reclamation of drastically disturbed lands. Agronomy 41, 371-398. ASA, CSSA, SSSA. Madison: Wisconsin USA Publishers.

Torbert, J. L., Burger, J. A., Daniels, W. L., et al. (1990). Pine growth variation associated with overburden rock type on reclaimed surface mine in Virginia. Journal of Environmental Quality, 19, 88-92.

Vanclay, J.K., 1994. Modelling forest growth and yield: applications to mixed tropical forests. CAB International, Wallingford, U.K. PDF/text Source. Available from http://epubs.scu.edu.au/cgi/viewcontent.cgi?article= $1538 \&$ context $=$ esm_pubs

Van Reeuwijk, L. P. (1995). Procedures for soil analysis, fifth edition. Technical paper 9. Wageningen: ISRIC, FAO.
Wali, M. K. (1999). Ecological succession and the rehabilitation of disturbed terrestrial ecosystems. Plant and Soil, 213(12), 195-220.

Wali, M.K.,\& Freeman, P.G (1973) Ecology of some mined areas in North Dakota. In M.K. Wali (Eds.), Some environmental aspects of strip mining in North Dakota (pp. 2547). Education Series 5. Grand Forks: North Dakota Geological Survey

West, T. O., \& Wali, M. K. (2002). Modeling regional carbon dynamics and soil erosion in disturbed and rehabilitated ecosystems as affected by land use and climate. Water, Air, and Soil Pollution, 138(1-4), 41-163.

Zipper, C. E., Burger, J. A., Skousen, J. G., Angel, P. N., Barton, C. D., Davis, V., et al. (2011). Restoring forests and associated ecosystem services on Appalachian coal surface mines. Environmental Management, 47, 75176. 